\title{
Fiatal Geográfusok Országos Találkozója
}

\section{National Meeting of Young Geographers}

\author{
VARGA ERNA
}

2011. április 13-14. között, a hagyományteremtés reményében konferenciát rendeztek Szegeden azzal a céllal, hogy a hazai tudományegyetemek földrajzképzésben részt vevő hallgatóit összehozzák a képzési tapasztalatok és a diploma utáni elhelyezkedési lehetőségekről szóló információk megosztására, aktuális kutatási témáik bemutatására, megvitatására. A tisztán hallgatói kezdeményezésre szervezett találkozó ötletét a (korábban éveken át megrendezett) Geográfus Doktoranduszok Országos Konferenciája adta, amelynek hagyományát egy átmeneti szünet után a 2009-es esztendőben élesztették újra, helyszínéül pedig azóta a Szegedi Tudományegyetem szolgál. Ezen rendezvénysorozat sikereiből merítve a fiatalabb generáció is felbuzdult egy hasonló jellegű, az alap- és mesterképzésben tanuló geográfus-hallgatókat megszólító program megteremtésére. Az eseményen a négy meghívott intézmény közül három, az Eötvös Loránd, a Pécsi és a Szegedi Tudományegyetem képviselői jelentek meg.

A találkozó első napja a részt vevő egyetemek bemutatkozásával és szakmai előadásokkal telt. Bajmócy Péter, a Szegedi Tudományegyetem Gazdaságés Társadalomföldrajz Tanszékének docense hivatalos megnyitóját követően a hallgatóság betekintést nyerhetett a három megjelent intézmény földrajzszakjainak közös és eltérő vonásaiba. Az egyetemi hallgatók bemutatták saját képzésük jellegzetességeit, hagyományait, a náluk elsajátítható szakirányokat és a kapcsolódó fontosabb tantárgyakat, hagyományos kutatási témákat.

A geográfia iránt érdeklődő egyetemi hallgatók összességében kevés lehetőséget kapnak hazai és külföldi konferenciákon való részvételre, ezért a rendezvény kitűnő alkalmat teremtett arra is, hogy kipróbálják magukat egy tudományos tanácskozás keretében, fejlesszék előadói képességüket, és aktívan hozzászóljanak földrajzi vitakérdésekhez. Jelen találkozón a szakmai elöadások két szekcióban zajlottak, a természet- és a társadalomföldrajz szétválasztásával. Az utóbbi területet képviselő hallgatók előadásainak - különösen két

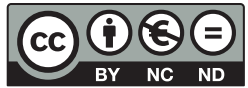


megjelent egyetem esetében - legszembetűnőbb jellemzője volt, hogy a diákok által felvonultatott társadalom-földrajzi problémák, kutatási témák tagadhatatlanul tükrözték anyaintézményük földrajzképzésének jellemzőit, az ott működő tudományos iskolák szemléletét, kiemeltebb vizsgálati kérdéseit. A komplex elemzői felfogást tükröző regionális tudományi megközelítés erősen áthatotta az ELTE előadóinak prezentációit, míg a PTE hallgatói a turizmusföldrajz kérdéskörébe engedtek mélyebb betekintést. Természetesen a terület- és településfejlesztés témaköre - mint a hazai geográfusképzés „slágerterülete" - mindhárom egyetem képviselőinek előadásában megjelent. A továbbiakban egy-egy érdekes vizsgálati téma segítségével mutatom be, hogy milyen sokszínü területet fog át a hallgatók földrajzi érdeklődése.

Farkas Máté Bence, az ELTE geográfus-hallgatója Spanyolország területi fejlettségi különbségeit és fejlődési tengelyeit vizsgáló tudományos munkájának eredményeit tárta a társadalom-földrajzi szekció közönsége elé. A fejlettségi különbségek vizsgálata során kettő, NUTS 3-as területi szinten is rendelkezésre álló mutatószám, a GDP/fö és a munkanélküliségi ráta több évtizedet átfogó változásait, összefüggéseit értékelte, és következtetett ebből a spanyol provinciák közötti egyenlőtlenségek történelmi alakulására. A két mutatószámmal kapcsolatban joggal merülhet fel a kérdés, hogy az előadó elegendőnek tartja-e azokat a fejlettség megragadására, ám az előadás során bemutatott eredmények így is érdekes következtetéseket fogalmaznak meg a témát illetően. A szakirodalom a XX. század második fele során tapasztalt folyamatok hátterében húzódó egyik kiemelkedő tényezőként a migrációt nevezi meg, ennek empirikus úton történő alátámasztására tesz kísérletet a fiatal kutató. A vándorlások meghatározó szerepe figyelhető meg többek között az 1970-es évek végéig is, amikor a gazdagabb területek irányába lendületet vett belső migráció következtében az elvándorlók kiindulási területén a népességszám csökkenése és az egy főre jutó GDP látványos növekedése között erős kapcsolat érzékelhető. Az előadó az ország területén kirajzolódó fejlettségi tengelyeket is kimutatja, 3 nagyobb gerincterületet ír le: az Atlanti-, a Mediterrán-, az Ebro-völgyi tengelyt (Farkas 2011).

Orbán Kristóf, a Pécsi Tudományegyetem előadója városföldrajzi megközelítésű munkájában a hazai lakótelepeket új szempontból vizsgálja tipizálással és a jövőbeli perspektívák átgondolásával. Kérdőíves felméréseinek eredménye szerint a lakótelepeken élők az általános negatív megítéléssel (például elnyomottság, zsúfoltság) szemben mégis élhető környezetként festik le ezen területeket, azaz lényeges különbség tapasztalható az ott lakók és nem ott lakók képzete között. Az előadó szerint a városok lélekszámának növekedése, a reurbanizációs folyamatok fellendülése még inkább indokolja a lakótelepek revitalizációját, a városi térben betöltött szerepük újraértékelését, a telepszerủ beépítés racionális és szükséges voltát hangsúlyozva. Más kérdés, hogy az Orbán Kristóf által vázolt előnyök ellenére a hazai, elsősorban a szocialista korszakból származó telepek a lassan beinduló korszerüsítések 
mellett sem értékelődtek fel eddig markánsan az ingatlanpiacon. Ezt követöen Orbán a szakirodalomban fellelhető lakótelep-definíciók számbavétele, értelmezése alapján önállóan tesz kísérletet bizonyos típusok kialakítására, továbbá a hazánkban ismert fóbb lakótelepeknek a városi pozíció és fizikai környezet szempontjából való besorolására. Ezek alapján három fö típust alkotott meg (városközpont, átmeneti és határ(talan) típus), ezeken belül altípusokat is elkülönítve (Orbán 2011).

Vedrédi Katalin a Szegedi Tudományegyetem képviseletében a szegedi közösségi terek fejlesztési lehetőségeinek vizsgálatával vezette be a résztvevo"ket a helyi településfejlesztés problémáiba. A döntően kvalitatív módszerek (kérdőívek, interjúk, médiaelemzések) felhasználásával végzett kutatómunka két esettanulmány segítségével igyekezett feltérképezni a város fejlesztési politikájának hiányosságait. Kiemelt problémának tekinti, hogy az elmúlt években bekövetkezett köztérfejlesztési programok felülről vezérelt átalakítások voltak, ahol a szereplők közötti kommunikáció meglehetősen gyengének bizonyult, ezáltal folyamatos konfliktusokat eredményezett. Ezen kérdések kezelése az előadó véleménye szerint azért lényeges, mert a városi közterek nem csupán fizikai elemei egy-egy településnek, hanem a lakosság identitásformálásában is kitüntetett jelentőséget kapnak. Vagyis a cél nemcsak a külső felújítás, hanem a terek tartalommal való megtöltése. Az előadó összességében azt a - véleményem szerint a szakmabeliek számára nem új, ám az ismételten megtapasztalható hiányosságok miatt folyamatos megerősítésre váró - végkövetkeztetést vonta le, hogy a fejlesztési folyamat elengedhetetlen lépése olyan felmérések készítése, amelyek a hétköznapi térhasználók igényeit és szokásait jobban tükrözik.

A szegedi találkozó második napja a geográfusképzés és -szakma értékét, perspektíváit áttekintő kerekasztal-beszélgetések jegyében telt. A vitaülést a Szegedi Tudományegyetem két oktatója, Mezősi Gábor és Pál Viktor vezette. $\mathrm{Az}$ alkalom kiváló lehetőséget nyújtott arra, hogy a hallgatók kifejezzék saját véleményeiket, megosszák egymással tapasztalataikat, amit az egyetemen és a szakmai gyakorlatok keretében szereztek. Mezősi Gábor először azt a gondolatát fejtette ki, hogy az elmúlt évek oktatási tapasztalata alapján az általános földrajzismeret a szakirányos ismeretekkel szemben erősen háttérbe szorult, a képzésben részt vevő hallgatók identitása sokkal inkább kötődik választott szakirányukhoz, mint egy, a természeti és társadalmi kérdéseket összetett megközelítésben vizsgálni képes földrajztudóshoz. Főképpen ennek köszönhető, hogy még a hallgatók fejében sincs egészen kialakult kép arról, hogyan látják magukat geográfusként (nem csupán területfejlesztőként, térinformatikusként stb.). Emellett mind a tanárok, mind a diákok részéről általános egyetértéssel fogalmazódott meg a túlképzés problémája, amivel persze nem csupán a földrajz szak, hanem a felsőoktatás nagyobb része is küzd napjainkban. A geográfus-diplomát szerzett fiatalok azonban abban a tekintetben még nehezebb helyzetben vannak, hogy a hazai 
viszonylatban új, közel két évtizedre visszatekintő szak (korábban csak földrajzszakos tanárképzés volt, a később kutatói pályát választók is mind tanárszakon végeztek) a munkaerőpiac számára még többé-kevésbé ismeretlen annak ellenére, hogy a geográfusok jelenléte az elmúlt években egyre érzékelhetőbbé vált. Mindezek következtében az egyetemek és a végzett hallgatók feladata, hogy megmutassák, a geográfus-képesítés milyen, illetve hol hasznosítható egyedi képességekkel, szemlélettel vértezi fel az oktatási intézmények falai közül kikerülő diákokat.

A találkozó átfogó üzenete a kerekasztal-beszélgetések és a színvonalas tudományos előadások alapján egyértelműen megfogalmazódott a résztvevőkben: a szakmai érdeklődés, a tudományos munkákba való bekapcsolódás, a képzésben elsajátítható tudás megszerzése mellett az egyéni képességek hatékony és tudatos építése, valamint a többi egyetemen folyó munka megismerése a geográfusként való sikeres érvényesülés nélkülözhetetlen feltétele. Reméljük, hogy a 2012. évben Pécsre tervezett második találkozó legalább ilyen eredményesen járul hozzá az ország geográfus-hallgatói közötti szakmai kapcsolat erősödéséhez.

\section{Irodalom}

Farkas M. B. (2011): Területi fejlettségi különbségek és fejlődési tengelyek Spanyolországban a XX. század második felében. OTDK-dolgozat, ELTE TTK Regionális Tudományi Tanszék, Budapest

Orbán K. (2011): A magyarországi lakótelepek újraértékelése. A fizikai környezet és a városi pozíció jelentősége. OTDK-dolgozat, PTE TTK Társadalomföldrajzi és Urbanisztikai Tanszék, Budapest 